UDK: 811.111'37

DOI: $10.33669 / \mathrm{KJ} 2021-32-07$

primljeno / received: 6. 10.2021.

prihvaćeno / accepted: 16. 12. 2021.
Pregledni naučni rad

\section{Amina Arnautović}

Fakultet islamskih nauka

Univerziteta u Sarajevu

Ćemerlina 54, 71000 Sarajevo

Bosna i Hercegovina

amina.arnautovic@fin.unsa.ba

\title{
Konotacije leksičkog sloja motiva stida u engleskim prijevodima bošnjačke balade "Hasanaginica"
}

Sažetak: Prevođenje književnoumjetničkog djela, posebno poezije, podrazumijeva i prevođenje njegova stila. Na leksikostilističkom nivou stil se manifestira kako denotativnim tako i konotativnim značenjem leksičkih jedinica koje sačinjavaju tekst. Analizom konotacija leksičkog sloja motiva stida u engleskim prijevodima bošnjačke balade "Hasanaginica" nastojimo utvrditi i problematizirati načine na koje je ovaj motiv interpretiran u ciljnim tekstovima u odnosu na izvornik. Metodom leksikostilističke analize ključnih stihova motiva stida, kako u izvorniku tako i u ciljnim tekstovima na engleskom jeziku, ispitujemo načine na koje različiti prevoditelji grade ovaj mistični motiv kao jedini apstraktni pojam koji se ne razvija u poetsku sliku te stječemo uvid u višeslojne konotacije koje se u prijevodima ova tri ključna stiha nameću čitatelju. $\mathrm{Na}$ osnovu rezultata analize određeni prijevodi su ocijenjeni kao najbliži izvorniku u smislu minimalnih razlika u stepenu interpretacijske ograničenosti / nametljivosti. Leksičkim izborom najzornije dočaran ključni stih motiva stida nalazimo u prijevodu Francisa Jonesa. Međutim, na konačni izbor leksike stilski osviještenog prevoditelja utječu i drugi aspekti izvornog teksta, poput njegova metričko-ritmičkog obrasca koji zahtijeva očuvanje i formalnih karakteristika ove balade, što Jonesov prijevod ne čini. Stoga zaključujemo da rezultate leksikostilističke analize izvornika valja odvagati u odnosu na rezultate analize i ostalih jezičko-stilističkih nivoa izraza (fonostilističkog i sintaksostilističkog) radi njihove što uspješnije sinteze koja bi rezultirala efektnijim i vjerodostojnijim prijevodom ovog usmenoknjiževnog remek-djela.

Ključne riječi: leksikostilistička analiza, konotacije, motiv stida, engleski prijevodi bošnjačke balade "Hasanaginica" 


\section{Uvod}

\subsection{Problem i predmet istraživanja}

Prevođenje književnog djela je, $u$ jednu ruku, i prevođenje njegova stila, s obzirom na to da je upravo stil ona komponenta teksta koja ga i čini književnim. Kao neposredni odraz autorova izbora, stil često postaje i nositeljem značenja. Smatrajući jezičku strukturu književnog djela vječnim središtem književnog proučavanja, a stil njegovom književnotvornom komponentom, opredijeljeni smo za lingvostilističku analizu kao osnovni pristup književnom djelu. S obzirom na činjenicu da je lingvostilistička analiza otvoren i nedovršen sistem opisivanja i komentiranja jezičko-stilskih obilježja i njihove funkcionalnosti u piščevu / pjesnikovu izrazu, stava smo da ona može kazati puno o umjetničkom izrazu te pomoći boljem razumijevanju književnoumjetničkog djela, što je, opet, jedna od osnovnih pretpostavki za njegovo uspješno prevođenje u drugi jezik. Kao jedan od osnovnih dijelova lingvostilističke analize, leksikostilistička analiza je temelj na osnovu kojeg predstojeći rad ispituje i problematizira način interpretacije i prenošenja motiva stida u engleskim prijevodima bošnjačke balade "Hasanaginica" s posebnim osvrtom na konotacije leksičkog sloja jezika.

\subsection{Svrha i ciljevi istraživanja}

Svrha rada je doprinijeti unapređenju prevodilačke prakse podizanjem svijesti o značaju prevođenja stilskog sloja teksta kojem se u samom procesu prevođenja rijetko pridaje dovoljno pažnje. Cilj rada jeste, na konkretnim primjerima prevođenja motiva stida, pokazati kako nedosljedno prenošenje stilskog sloja teksta u engleskim prijevodima bošnjačke balade "Hasanaginica" bitno utječe na njegov semantički ili značenjski sloj.

\subsection{Metodologija rada}

Rad se koristi metodom leksikostilističke analize, koja je tek jedan važan dio lingvostilističke analize teksta. Leksičko-stilskim raslojavanjem 
teksta izvornika, kao i ciljnih tekstova njegova prijevoda na engleski jezik, nastoji se ukazati na propuste nastale prilikom prevođenja predmetnog motiva u engleski jezik.

Nakon utvrđivanja problema i predmeta istraživanja, svrhe i ciljeva, metodologije, kratkog pregleda dosadašnjih relevantnih istraživanja te pregleda korpusa u uvodnom dijelu, osnovni dio rada nudi interpretaciju motiva stida, zatim definiciju pojma konotacije u odnosu na pojam denotacije kao ključnog pojma na osnovu kojeg se prezentiraju rezultati analize prijevoda predmetnog motiva (stihovi 7, 8 i 9), da bi se $u$ završnom dijelu rada donijeli zaključci s obzirom na svrhu i definirani cilj istraživanja.

\subsection{Pregled dosadašnjih istraživanja}

Rad se temelji na opsežnoj lingvostilističkoj analizi, kojom se autorica bavila u sklopu izrade doktorske disertacije pod naslovom Lingvostilistička analiza engleskih prijevoda Hasanaginice (Arnautović 2017). Sama disertacija predstavlja prvu i jedinstvenu analizu ovoga tipa provedenu na tekstu izvornika i ciljnim tekstovima objavljenim na engleskom jeziku.

U kontekstu dosadašnjih istraživanja o prijevodima balade "Hasanaginica" na engleski jezik, možemo spomenuti više autora, koji su se bavili različitim aspektima balade. Naprimjer, Vasa D. Mihailovich je 1986/87. god. objavio kraći naučni rad koji komentira metričko-ritmički obrazac 22 prijevoda ove balade na engleski jezik. Određene (ranije) prijevode balade "Hasanaginica" na engleski jezik proučavali su i komentirali Dragutin Subotić, Svetozar Koljević i Mira Janković. Na Fakultetu humanističkih nauka u Mostaru, Nerin Dizdar je odbranio magistarski rad s nazivom Semantički i sociolingvistički aspekti engleskih prijevoda balade "Hasanaginica". Mnogi autori širom svijeta su iz različitih aspekata pisali o ovoj baladi, među kojima nalazimo i najistaknutije slaviste svoga vremena poput A. Mickijevicza, F. Miklošiča, R. Medenice i dr. Međutim, sva istraživanja o ovoj baladi koja su prethodila spomenutoj doktorskoj disertaciji bila su tek polazna osnova za 
jednu dublju, višedimenzionalnu jezičko-stilističku analizu izvornika i njegovih prijevoda na engleski jezik.

Ovaj rad tematizira načine na koje je interpretiran i prevođen motiv stida u engleskim prijevodima balade "Hasanaginica" na način na koji to ranije nije rađeno, s ciljem koji nadilazi sami predmet analize te može poslužiti i kao uopćeni primjer prevoditeljima poezije.

\subsection{Korpus}

Do danas, balada "Hasanaginica" prevođena je 25 puta na engleski jezik. ${ }^{1}$ Od tih 25 objavljenih prijevoda, 14 ih je sačinjeno na osnovu Goetheovog prijevoda na njemački. Goetheovu verziju je prvi preveo Sir Walter Scott krajem 18. stoljeća (179?), a svoj prijevod je nazvao "The Lamentation of the Faithful Wife of Asan Aga". Potom su uslijedili prijevodi Johna Boyda Greenshieldsa (1800), Felicije Dorothee Hemans (1821), Johna Bowringa (1827), Jamesa Clarencea Mangana (1836), Williama Edmondstouna Aytouna (1844), Edgara Alfreda Bowringa (1853), Mary Anne Burt (1853), te Georgea Bancrofta (1855), Owena Mereditha $^{2}$ (1861), Edwarda Chawnera (1866), Paula Dyrsena (1878), Williama Gibsona (1883) i M. Gray ${ }^{3}$ (1890). Godinu nakon što je Paul Dyrsen objavio svoj prijevod balade, Kate Freiligrath Kroeker objavljuje svoj prijevod (1879) najvjerovatnije TALVJ-evog ${ }^{4}$ prijevoda na njemački. Prevoditelji balade iz 20. stoljeća su: George Rapall Noyes i Leonard Bacon (1913), ${ }^{5}$ Maximilian August Mügge (1916), ${ }^{6}$ Robert William

Ovdje računamo samo njezine objavljene prijevode.

2 Owen Meredith je pseudonim kojim se koristio Edward Robert Bulwer Lytton, koji je prvobitno tvrdio da je njegov prijevod balade prijevod originala, da bi nešto kasnije povukao tu svoju tvrdnju.

3 Puno ime ovog autora prijevoda balade je nepoznato. Pojavljuje se isključivo u navedenom obliku.

4 TALVJ je pseudonim kojim se koristila Therese von Jacob, udato Robinson.

5 Prvi engleski objavljeni prijevod s jezika izvornika. Ovo je prijevod verzije Vuka Stefanovića Karadžića.

6 Prijevod se smatra plagijatom prijevoda J. Bowringa, jer su 43 stiha identična, a 14 stihova vrlo slični Bowringovoj verziji, što upućuje na činjenicu da je polovina prijevoda balade zapravo djelo Bowringa. I sam Mügge (1916) obavještava čitatelja kako je veći broj pjesama u svojoj knjizi preuzeo od J. Bowringa, te ih revidirao. 
Seton-Watson (1932), ${ }^{7}$ Duncan Wilson (1970), Thomas Butler (1980), Vasa D. Mihailovich (1983), ${ }^{8}$ Anne Pennington i Peter Levi $(1983)^{9}$ te Zora Devrnja Zimmerman (1986). ${ }^{10}$ U 21. stoljeću se pojavljuju zasad posljednji prijevodi balade: Francisa Jonesa iz 2010. godine "The Sad Ballad of the Noble Lady Hasan Aginica" te prijevod Amire Sadiković, nastao prevođenjem knjige Sevdah autora Damira Imamovića 2017. godine. ${ }^{11}$

\section{Rezultati analize}

\subsection{Interpretacija motiva stida}

Obavijenom velom tajanstvenosti, o baladesknom motivu stida raspravljali su mnogi naučnici, učinivši ga tako još mističnijim i zagonetnijim. Tako je Camilla Lucerna (1905: 44) tumačila stid kao baštinu ondašnje žene, morala, načina života i običaja, ponekad i pogrešno, naprimjer, kada dugu koprenu (pul'duvak u baladi) percipira kao simbol straha i zebnje od svakog dodira, simbol jednog zlostavljanog bića. Pul'duvak se u baladi, zapravo, vrlo jasno pojavljuje kao simbol zaštite. Ova koprena je štit kojim Hasanaginica hoće da zakloni dječije poglede kako ne bi bili svjedoci odvođenja vlastite im majke, ali i da odbrani sebe od vlastitih emocija pri susretu s djecom. Koprena tako postaje simbol delikatnosti njezinog odnosa kako prema drugima tako i prema samoj sebi. I Hatidža Krnjević (1973: 275) je procijenila Lucerninu studiju i interpretaciju balade kao najbolju u onom njezinom dijelu u kojem “žena kazuje o ženi na planu psihološkog zapleta, ali samo dotle dok ne iskrsne pitanje određenog mentaliteta, nacionalnih svojstava, zakona patrijarhalne porodice - svega onoga što tu baladu čini muslimanskom i našom". Lucerna, kao što i Krnjević primjećuje, ne osjeća duh vremena i atmosferu porodičnog života, niti razumije ondašnje društvene i moralne norme i običaje kada tvrdi da brat postupa sa sestrom kao da je

\footnotetext{
Prijevod verzije Ivana Meštrovića.

Prijevodi Wilsona, Butlera i Mihailovicha su prijevodi Vukove verzije.

Prijevod verzije Miroslava Pantića.

10 Prijevod Vukove verzije.

11 Prijevod verzije Hatidže Krnjević.
} 
kakva stvar. Njezina interpretacija balade je, ipak, interpretacija jednog stranca iz perspektive drugog svijeta i druge kulture.

Suprotno interpretaciji autorice Kamile Lucerna, Muhsin Rizvić (1994: 141), kao bolji poznavatelj socijalne stratifikacije ondašnje društvene sredine u kojoj je ova balada nastala, u svojoj analizi socijalnih aspekata balade, tumačio je i stid kroz prizmu strukture socijalnih odnosa u Hasan-aginoj kući i njegovoj porodičnoj zajednici, ističući svoj stav kako "Stid u ovoj baladi treba razumijevati kao socijalno-emocionalnu kategoriju suprotnu ponosu, inače tradicionalno vezanom za begovat: i to u odnosu subjekta s obzirom na objekat prema široj društvenoj sredini", na osnovu čega "Hasanaginica po inerciji socijalne psihologije svoga staleža može osjećati stid zbog položaja u koji je kao begovica zapala udajom za (...) agu, tj. čovjeka njoj nejednakog po rodu i socijalnom položaju”. Dakle, Rizvić nastoji ukazati na kompleksnost ovog strukturnog pojma cijele balade, koji je s jedne strane činjenica socijalno-klasne psihologije Hasanaginice, a s druge strane, u tuđoj (svekrvinoj), Hasan-agi nametnutoj interpretaciji, socijalno podbadanje muževljeva ponosa, te raspirivanje njegovih socijalnih kompleksa kako bi on osjetio potrebu za osvetom ženi koja, prema njegovom (Hasan-aginom) uvjerenju, zapravo nema nikakva stida. Na taj način Rizvić pokazuje lik Hasanaginice kao "raslojen na dvije dimenzije: na ponos begovice $\mathrm{i}$ ravnodušnost prema Hasan-agi, i na osjetljivost i ljubav prema djeci”, sa zaključkom da ovakva interpretacija možda umanjuje "kompaktnost" Hasanaginicinog "etičko-emocionalnog lika", ali da istovremeno "humano svjedoč[i] o Hasanaginici kao žrtvi begovsko-kastinskih kanona, staleških predrasuda i socijalno-klasne psihologije" (Rizvić 1994: 151).

Dok motiv stida prema Rizviću krije tajnu prethodnog zbivanja balade, Radosav Medenica (Krnjević 1973: 275) ga ne smatra velikom tajnom koju treba odgonetnuti. Henrik Barić (1938: 169), opet, objašnjava stid kao stvarni lični osjećaj Hasanaginice čija pasivnost jeste "osnovna crta njenog bespomoćnog utapanja u tom mentalitetu s kojim je srasla”. Oprečno Matiji Murku, Krešimir Gregorijević (1952: 50) smatra da je Hasanaginicin stid nemoguće objasniti isključivo društveno obespravljenim položajem žene, već da mu je potrebno dodati i težinu tradicije 
feudalnog društva koja je odnos između supružnika smatrala grešnim i nečim što je trebalo kriti. Gerhard Gesemann smatra interpretaciju Lucerne o Hasan-aginoj čežnji za aktivnom i otvorenom ljubavlju patetičnom i tvrdi da se stid ne može objasniti "folklorističkim razlozima", jer su nam javni i privatni običaji i shvatanja vremena i sredine u kojoj je živio pjesnik ove balade zapravo nepoznati. Nadalje, Gesemann zaključuje da ženin stid ne potječe bezuvjetno iz općeg morala, već samo odgovara tom moralu, a ustvari predstavlja ličnu osobinu žene, njezinu psihološku osobinu. Iako Gesemann smatra ulogu stida često precijenjenom, priznaje da je oblik i smisao tog stida jedinstven i neponovljiv, budući da je riječ o pokretačkom principu, uzroku i povodu baladesknog događaja - stidu koji se uzdiže do stepena kobne greške (Gesemann 1923: 18-20).

Jednu novu i neobičnu interpretaciju stida nalazimo kod Aleksandre Wagner, ${ }^{12}$ koja u pojam stida učitava zapažanja modernog uma i način razmišljanja nesvojstven ženi ondašnjeg društva, te potpuno zanemarujući mogućnost stida kao usvojene moralne norme i obrasca ponašanja žene muslimanke onoga doba, smatra da ono što Hasanaginicu sprečava od odlaska ranjenom mužu jeste vlastita sposobnost poistovjećivanja s ranjenim Hasan-agom, s njegovim stidom i posramljenošću skrhanog ratnika. Međutim, u ovakvom promišljanju postoji jedna kontradiktornost, naime, zašto bi se Hasan-aga rasrdio na ženu koja nije došla da ga obiđe kada je bio u stanju u kakvom ni sam ne bi želio da bude zatečen, ponajmanje od svoje žene. Wagner tu nelogičnost objašnjava tako što tvrdi da je Hasan-aga shvatio pravi razlog ženina izostanka - ona ga je htjela poštedjeti stida koji bi osjećao pred njom zbog svog jadnog stanja, te tako spasiti njegovu muškost - čime ona u očima Hasan-age, umjesto da ostane emocionalni produžetak njega samog, postaje zasebna ličnost, razdvajajući se od njega u svojoj neovisnoj Drugosti. Hasan-aga, dakle, pušta ženu koja zna previše, upravo zbog nepoželjne oštrine njezina uma, iz straha da bi to saznanje mogla prenijeti na djecu, te ih učiniti još

12 Bakalaureat iz komparativne književnosti i filozofije stekla na Univerzitetu u Sarajevu. Trenutno u zvanju docenta iz oblasti sociologije, The New School, New York City. Društvene dimenzije stida je jedan od predmeta koje predaje. 
nepredvidljivijim individuama od nje same, što bi moglo bitno narušiti imidž i autoritet age kao oca (Wagner 2008).

Stid Hasanaginice su na svoje načine interpretirali i drugi autori, poput Jasmina Hodžića, ${ }^{13}$ koji se nadovezuje na ideju Mahmutćehajića, ${ }^{14}$ a koju također preuzima i Nerin Dizdar. ${ }^{15}$

Interpretacije motiva stida u ovoj baladi su mnogobrojne i šarolike, a ono što je zapravo najbliže istini jeste činjenica da nepoznati autor balade očigledno nije imao potrebu da posebno motivira ili objašnjava stid, na osnovu čega se može zaključiti da je taj stid vjerovatno bio razumljiv ondašnjem slušatelju balade. Osim toga, balada počiva na principu redukcije s kojom je nedorečenost usko povezana. Stid glavne junakinje bez kojeg ne bi bilo ni sukoba u baladi je, kako Krnjević (1973: 280) primjećuje, neodređen i zagonetan u još jednom smislu, naime jer predstavlja "apstraktan pojam” kakvim se narodni pjesnik rijetko služi iz prostog razloga što narodna poezija jeste "mišljenje u slikama” ili kako je Muratagić-Tuna (2010: 15) opisuje "metamorfoza riječi u poetsku sliku”. Dok apstraktni pojam straha i osjećaj sramote "imaju svoj konkretni ekvivalent u slici, misli, riječi ili činu, tako prvobitni stid ostaje isti, ne razvija se u sliku” zbog čega je upravo stid ostao trajno prisutan i za mnoge nerješiv problem (Krnjević 1973: 280). Krnjević (1973: 280-281) logički rasuđuje u razmatranju drugih muslimanskih pjesama sličnih baladi "Hasanaginica", upravo prema ovom detalju, u kojima se stid vezuje za ženin pohod mužu ranjenom u ratu, daleko od kuće u vojničkom taboru, zaključujući da takvo šta jednostavno nije bio običaj,

13 Posredstvom novog kulturološkog čitanja balade "Hasanaginica" ovaj autor interpretira zagonetni stid kroz prizmu shvatanja Hasanagina boravka u planini kao "privremene rastave" (darb) supružnika, kao posljednjem koraku pred razvod braka zbog neke njene krivnje, jer su, po izvjesnoj porodičnoj predaji, sve žene u familiji kojoj pripada Hasanaginica ters žene.

14 Rusmir Mahmutćehajić nudi jednu novu interpretaciju "Hasanaginice" s aspekta muslimanskog ezoteričkog naslijeđa, u kojoj baladu uzdiže do djela sakralne umjetnosti. U svojoj isključivo filozofskoj interpretaciji (bez uporišta u nauci o jeziku) Rusmir Mahmutćehajić pronalazi intelektualne i književne dubine i razotkriva tajne unutar parametara perenijalne filozofije neodvojive od muslimanske intelektualne misli. U ovom čitanju, balada postaje sredstvo kojim se Bog na različite načine obznanjuje u riječima i slikama.

15 Ovaj autor preuzima Mahmutćehajićevu interpretaciju u vezi s aginim svojevoljnim osamljenjem u planini. 
naročito ne u muslimanskoj sredini, dodajući da je stid "prvo u čemu se žena očituje", te da je kao takav upravo stid "pokrenuo sudbonosno zbivanje i doveo do onako intenzivnog ispoljavanja materinske ljubavi”. Ko poznaje mentalitet i običaje bosansko-muslimanske sredine (posebno kada je riječ o begovskim porodicama), u kojoj naše stare nane i danas još govore o "sramoti" i nedopustivosti javnog ispoljavanja osjećanja među supružnicima, ili o crvenilu na licu kao znaku stida i moralne vrline i slično, taj lahko može prepoznati i shvatiti Hasanaginicin stid, koji kao moralna vrlina prvog reda krasi junakinju ove balade. Stih kaže: "A ljubovca od stida ne mogla”, povezujući tako Hasanaginicin stid s njezinim svojstvom žene i supruge, a što nema nikakve veze sa spomenutim Gregorijevićevim shvatanjem odnosa između supružnika grešnim. Dapače, odnos između supružnika u islamu je uzvišen i poželjan, ali se istovremeno kroz mnoge hadise govori i o njegovoj intimi i potrebi da se taj odnos, iz mnogih i složenih razloga, a prije svega radi njegova očuvanja, zadrži intimnim i zaklonjenim od javnosti.

\subsection{Konotacije leksičkog sloja motiva stida}

Konotacija (lat. connotatio $=$ zabilježiti) kao kognitivna aktivnost pristupanja asocijacijama koje povezuju određenu riječ i njeno značenje, u lingvističkoj i književnoteorijskoj literaturi određuje se u opreci prema denotaciji (koja upućuje na izvorno ili osnovno značenje) kao dodatna vrijednost ili stilski dodatak određenih riječi u datom kontekstu. Analizirajući leksiku kojom različiti prevoditelji grade mistični motiv stida kao jedini apstraktni pojam koji se ne razvija u poetsku sliku, a što je razlog otvaranju prostora za višeslojne konotacije koje se ovdje nameću čitatelju, došli smo do određenih rezultata koje ćemo ponuditi u sljedećem pregledu centralnog stiha ovog motiva u svim prijevodima balade na engleski jezik.

Tekst izvornika gradi motiv stida u samo tri stiha (stihovi 7, 8 i 9: "On boluje u ranama ljutim. / Oblazi ga mater i sestrica, / A ljubovca od stida ne mogla") sasvim dovoljna da se ovaj motiv uobliči na jedinstven i neponovljiv način kao pokretački princip, uzrok i povod baladesknog događaja. Inicijalna formula balade spjevana je u prezentu, 
kako bi dočarala i približila baladesknu radnju slušatelju / čitatelju, što je bitna činjenica, budući da se kontinuitet radnje u prezentu nastavlja u sedmom i osmom stihu, da bi na samom kraju devetoga radnja neočekivano skrenula u krnji perfekt, što doprinosi efektu uzvičnosti i začudnosti: "A ljubovca od stida ne mogla". Efekt ne bi bio jednako snažan da je ovdje, kojim slučajem, upotrijebljen puni perfekt nije mogla. Ova uzvičnost i začudnost stvaraju dodatnu zapitanost nad samim motivom stida, čineći ga još mističnijim. Međutim, ono što nam leksičko-morfološki sloj ovih stihova denotativno poručuje ne može stišati uzvičnost, niti umanjiti začudnost i zapitanost, a da ne aktivira višeslojni konotacijski nivo iskaza. U kakvoj je vezi stalni epitet ranama ljutim s imenicom stid? Na kakve odnose između imenica "mater (i) sestrica" u osmom stihu i "(a) ljubovca” u devetom stihu upućuju veznici, u prvom slučaju sastavni veznik “i”, a u drugom rastavni "a”? Pojačavaju li ovi veznici dodatno antonimiju potvrdnog oblika glagola "oblazi” i odričnog oblika eliptičnog glagola "ne mogla (obići)", suprotstavljajući na taj način leksički sloj osmog i devetog stiha?

Pregled prijevoda centralnog stiha u motivu stida otkriva nam i šarolikost konceptualizacije samoga pojma stida kao mentalnog procesa $\mathrm{u}$ kojem se razjašnjava i konkretizira ovaj široki i neprecizni pojam, još širi i neprecizniji ako u obzir uzmemo vremenske i kulturološke razlike njegova poimanja.

Najčešće korištena engleska riječ za stid, koju nalazimo u jedanaest prijevoda, jeste imenica shame (ovdje ubrajamo i bliskoznačne pridjeve koji sadrže isti leksem: ashamed i shamefaced, te imenicu shamefacedness), što je razumljivo s obzirom na činjenicu da taj leksem ima i najširi spektar značenja obuhvatajući sve od "štete", preko inherentnog "stida", "srama" i "sramote", pa do "bruke" s jačim konotacijama s društvenim kontekstom. Međutim, ni korištenje istog leksema ne podrazumijeva jednaku konceptualizaciju pojma kod različitih prevoditelja.

Tako, naprimjer, Scott tautologijom timid shamefacedness u stihu "Timid shamefacedness compelled her to stay" (povratni prijevod: "Bojažljiva posramljenost prisilila ju je da ostane") opisuje karakternu crtu bojažljive i stidljive žene, slične onoj o kakvoj je i Gesemann govorio, na što 
Scott eksplicitno upućuje 17. stihom u kojem kaže da je "ona žalila više od najbrižnije majke" (She sorrow'd more than the fondest of mothers), predstavljajući nam na taj način dvostruko napaćenu Hasanaginicu, koja duboko pati i zbog muža (njegovog teškog stanja), ali i za njim, jer ga, "prisiljena" (compelled) svojim stidom, nije u stanju obići u "tijesnom šatoru, nabijenom rodbinom i prijateljima”. Dakle, u preopširnosti i eksplicitnosti svoga prijevoda, Scott jasno pokazuje vlastito poimanje ženinog stida čije porijeklo nalazi u dubokim emocijama, koje su dio njezine ličnosti. Stid je tako kod Scotta dvostruko naglašen, tj. s dva različita jezička sredstva, s jedne strane tautološkim izrazom, a s druge strane, sintaksom u kojoj stid postaje subjekat, odnosno vršitelj radnje u ključnom stihu ovoga motiva. Ovakvom se sintaksom koriste još dva prevoditelja, Greenshields koji u svom prijevodu predmetnog stiha "But modesty delay'd his Consort's footsteps" (povratni prijevod: "No, skromnost zadrža njegove Druge korake") koristi drugi leksem, tj. modesty, te Zimmerman koja u svom prijevodu ovoga stiha "But shame keeps Aga’s wife away" (povratni prijevod: "Ali stid drži aginu ženu podalje") koristi identičan leksem shame.

I $\mathrm{u}$ Meredithovu prijevodu ovoga stiha "But his wife, for the modest-minded shame / Of a matron chaste, could not" (u povratnom prijevodu: "Ali njegova žena, iz sklonosti k skromnosti proisteklog stida / gospođe čestite / čedne, nije mogla") nalazimo riječ shame s pridjevom modest-minded koji eksplicitno upućuje na porijeklo ženinog stida u njezinoj sklonosti ka skromnosti, umjerenosti i jednostavnosti. Pridjev koji Meredith koristi završava sufiksom -minded, koji se inače prilaže nekim pridjevima i prilozima da bi se dobio pridjev kojim se opisuje način na koji neko razmišlja ili nečiji stav prema životu. Već ovdje, dakle, imamo implikaciju da je stid koji sprečava Hasanaginicu da obiđe ranjenog muža pitanje njezina stava i načina razmišljanja kakvi priliče jednoj “čestitoj i čednoj gospođi” (engl. književni izraz za udatu ženu matron uz arhaični pridjev chaste), a što se potvrđuje i ostalim stihovima koji grade motiv stida u Meredithovu prijevodu, gdje se kaže da su majka i sestra došle u posjetu uz pojašnjenje u zagradi da su one bez krivnje mogle činiti što im je volja (for these without blame might do as 
they listed), aludirajući tako na jedan društveni kontekst u kojem "čestita žena" očito nije mogla učiniti što joj volja a da ne bude osuđivana od društva. Ova parenteza je ujedno i glas pripovjedača / narodnog pjevača, de facto prevoditelja, u čijem tonu je prepoznatljiva kritika društva i ondašnjih društvenih prilika koje ni sam nije najbolje poznavao niti razumijevao.

Zanimljiva, i nešto drugačija, konotacija u motivu stida se pojavljuje u Manganovu prijevodu devetog stiha "But his wife, too shamefaced, weeps at home" (povratni prijevod: "Ali njegova žena, isuviše posramljena, plače kod kuće"), gdje "ranjeni ratnik" (wounded warrior) "leži čeznući” (engl. arhaizam lieth pining), dakle, agu razara tuga jer ne može biti s voljenom ženom. Majka i "sestre", svi dolaze da ga služe, iskazujući svoju brigu za njega, samo njegova žena "isuviše posramljena, plače kod kuće". Ono što je u Manganovu prijevodu ovog motiva bitno jesu glagoli koji, u dva zasebna stiha (rastavljena stihom u kojem majka i "sestre" (pl. sisters) te svi ostali obilaze Hasan-agu), govore šta se zbiva s mužem, a šta sa ženom. Dok Hasan-aga "leži u čežnji” za ženom, ona sjedi kod kuće i roni suze za njim, jer je "isuviše posramljena” (too shamefaced) da se zaputi k njemu. Leksičko-semantička, ali i sintaksička povezanost ovih dviju radnji implicira na neki način i vezu između ženina stida i uzajamne čežnje ili žudnje supružnika. Manganova konceptualizacija pojma stida se može tako dovesti u vezu s ranije spomenutom Lucerninom interpretacijom o Hasan-aginoj čežnji za aktivnom i otvorenom ljubavlju, te s Gregorijevićevim shvatanjem odnosa između supružnika grešnim.

Leksemom shame se koriste i J. Bowring i Mügge koji nude identičan prijevod devetog stiha "But for very shame his wife is absent" (povratni prijevod: "Al' zbog samog stida njegova žena je odsutna”) kod kojih je žena "odsutna" upravo iz stida, Pennington i Levi "But his love is ashamed and cannot come" (povratni prijevod: "Ali njegova ljuba(v) je posramljena i ne može doći”), gdje je žena "posramljena i ne može doći", Aytoun "But his wife hangs back for shame, and comes not" (povratni prijevod: "Ali njegova žena se uzdržava zbog stida i ne dolazi”) čija se Hasanaginica “uzdržava iz stida, i ne dolazi”, kao i Kroeker "But 
for shame his wife is all unable" (povratno: "Al' iz stida njegova žena je sva nemoćna”) gdje je žena stidom spriječena da ide ranjenom mužu u pohode.

Amira Sadiković se koristi leksemom "ashamed" ("posramljena, postiđena") u prijevodu rimovanih stihova koji glase: "Injured in pain he lies, / Mother and sister give tender care, / But his wife, ashamed, did not dare" (u povratnom prijevodu: "ranjen u bolovima leži, / Mati i sestra pružaju njegu s nježnošću, / Ali njegova žena, posramljena, nije se usuđivala”). Upotrijebljeni pridjev "ashamed” implicira i određeni osjećaj krivice ili postiđenosti i zbunjenosti kod žene zbog vlastite greške ili osjećaja da nije opravdala očekivanja nametnutih joj standarda, dakle, ima jače konotacije s izvanjskim faktorima negoli unutrašnjim, tj. njenom osobenošću i prirodom, na koju najneposrednije upućuju leksemi modest (Greenshields, Meredith i Butler) i posebno demure, kojim se koristi samo Jones. Istim leksemom se koristi i Mihailovich: "But not his wife, for she is too ashamed" (povratni prijevod: "Ali ne njegova žena, jer ona je isuviše posramljena.”).

U Wilsonovu prijevodu "But for shame his dear wife would not come" (povratni prijevod: “Al iz stida njegova draga žena nije htjela doći”) koji se također koristi leksemom shame, nailazimo na drugačiju konotaciju u završnim riječima stiha, gdje autor ovoga prijevoda izvorni krnji perfekt "ne mogla" prevodi u would not come koji implicira htijenje / namjeru da ne dođe, za razliku od nemoći ili spriječenosti koja je implicirana u ostalim prijevodima. Uz ovu implikaciju, u Wilsonovu prijevodu nalazimo i fusnotu na kraju ovog stiha, u kojoj autor prijevoda objašnjava kako se:

Srce balade nalazi u ovom nejasnom stihu. Hasanagina žena nije došla da ga obiđe, jer je prema najstrožijem muhamedanskom zakonu bila obavezna čekati da je on pozove. On je očigledno pomislio da njoj nije bilo stalo do njega te je jednako pogrešno protumačio (na kraju balade) njeno nastojanje prvo da izbjegne susret, a zatim da se u dobrom raspoloženju oprosti od djece. Cijela priča je dobra ilustracija teškog zadatka prevođenja poezije, posebno pjesama čija su ključna mjesta jezgrovita s dosta aluzija i nagovještaja. (Wilson 1970: 63; naš prijevod). 
Ovakvu neprikladnu praksu napuštanja mikrokonteksta književnoumjetničkog djela zarad šireg kontekstualiziranja prijevoda komentirao je i Venuti (1998: 22), upozoravajući na negativne posljedice sličnog korištenja fusnota, zbog objektivnog rizika svođenja domaćeg čitateljstva na kulturnu elitu kojoj ova praksa akademskog diskursa nije strana. Osim Wilsona, još se i Noyes i Bacon ("For very shame his wife came not"), Seton-Watson ("But not his wife, his dear love Káduna / So young, so shy, she dared not go") te se Zimmerman na istom mjestu u svojim prijevodima koristi fusnotom, Noyes i Bacon kako bi skrenuli pažnju da je "ovu frazu umetnuo Karadžić", Seton-Watson kako bi pojasnio da je posebnu pažnju posvetio vlastitim imenima u svom prijevodu, a Zimmerman (1986: 242-243) kako bi, poput Wilsona, "demistificirala" zagonetni pojam stida uz poduže pojašnjenje prilika ondašnjeg društva, ${ }^{16}$ ženina ovisnog položaja i sramote da ide mužu u pohode, jer bi na taj način izrazila želju i brigu za njim, dodajući i opasku da su likovi balade Srbi koji su prešli na islam samo da bi zadržali svoje plemstvo. Inače, tri stiha koji grade motiv stida u prijevodu Zimmerman, u leksičkom smislu prilično su otvoreni za tumačenja, tj. nisu interpretativno ograničavajući, tako da bi se motiv stida u ovom prijevodu, da nije fusnote u kojoj se spominje bojište, mogao tumačiti i na posve drugačiji način. S obzirom na ono što ovi stihovi eksplicitno govore, tj. da aga "boluje od okrutnih / surovih / nemilosrdnih rana" (aches from cruel wounds), da ga majka i sestra "tješe" (comfort), ${ }^{17}$ "ali stid drži Aginu ženu podalje (od njega)”, njegov leksičko-semantički sloj bi mogao upućivati i na simboličko i metaforičko značenje kakvo su neki istraživači balade već spominjali (v. Nerin 2011), a prema kojem se frazem ljute rane ne mora odnositi na rane zadobijene u boju, već na njegovu vlastitu unutarnju "borbu", čemu bi u prilog išla i činjenica da se u šestom stihu govori o šatoru Age Hasan-age u jednini, a što bi moglo ukazivati na

16 Zimmerman govori o periodu od kasnog 15. do ranog 16. stoljeća, a balada "Hasanaginica" je, prema većini istraživača, nastala u periodu od druge polovice 17. pa do ranog 18. stoljeća. Ovo su činjenice koje ukazuju na neprikladno korištenje fusnota koje, osim što su neprikladne, sadrže i netačne i neprovjerene podatke koji se iznose kao tobožnje činjenice u jednom formalno akademskom stilu.

17 Zimmerman je jedina prevoditeljica koja je izvorni glagol "oblaziti” prevela glagolom "comfort" (tješiti), dok su drugi ovaj glagol prevodili glagolima: "posjetiti", "otići”, "doći”, "prisustvovati", "brinuti se o", "njegovati”, "služiti” i sl. 
Hasan-agino svojevoljno osamljenje, usljed određenih ličnih nedoumica. Međutim, na ovakvu konceptualizaciju stalnog epiteta "ljute rane" ne upućuje nijedan od analiziranih 25 prijevoda balade.

U Seton-Watsonovu prijevodu, koji se također služi fusnotom, Agi “idu u posjetu" (visit him) majka i sestra i nađu ga gdje "leži pogođen bolnim ranama" (lies stricken with grievous wounds), ali ne i njegova žena, "njegova draga ljubav Kaduna" (his dear love Kaduna), koja se "tako mlada, tako stidna" nije usudila (dared not) poći. Ovdje se javljaju različite konotacije u vezi s modalnim glagolom dare čija je stilska markiranost na višem nivou od iskaza koji upućuju na činjenično stanje ženina izostanka, tj. da nije došla, ili pak onih koji izriču nemogućnost njezina dolaska, tj. da nije mogla ili da je bila spriječena da dođe. Tako Seton-Watson već u motiv stida unosi i motiv straha, zapravo, ovdje je istaknut motiv straha, koji bi se mogao razumjeti pomoću motiva stida, tj. da žena nije smjela otići mužu jer je tako mlada (young), s implikacijom "neiskusna" i stidna (shy) s implikacijom "plašljiva / bojažljiva”, što se opet može dovesti u vezu i s muževljevim "bolnim ranama" i njegovim vrlo ozbiljnim fizičkim stanjem s kakvim bi se mlada i neiskusna osoba teško znala nositi. Međutim, teško je zamisliti ženu koja je rodila petero djece, ma u kojoj dobi bila, kao neiskusnu i bojažljivu u ovom smislu, tako da možemo zaključiti da su konotacije leksičkog sloja Seton-Watsonova prijevoda nepodudarne s onima na koje nailazimo u ovom motivu u tekstu izvornika. Na leksičko-stilističkom nivou, a u odnosu na tekst izvornika, ovakav prijevod motiva stida bi se mogao okarakterizirati kao interpretativno ograničavajući ili nametljiv jer aktivira nerelevantne vidove značenja, profilirajući jednako nerelevantne kognitivne domene kod čitatelja.

Ni kod autorice Sadiković se Hasanaginica ne "usudi" doći (did not dare), kao ni kod Bancrofta, s bitnom razlikom što Sadiković precizno prenosi glagolsko vrijeme, tj. izvorni perfekt, dok kod Bancrofta ovaj glagol ostaje u prezentu: "Stayed by bashful love, she dares not come". Bancroftova pasivna konstrukcija prvog polustiha do cezure, na sintaksičkom nivou ovoga stiha, objektivizira Hasanaginicu koja ovdje trpi radnju vlastite ljubavi kao agenta, usljed čega biva "zadržana stidljivom 
/ snebivljivom ljubavlju" (stayed by bashful love). Ovakva konstrukcija postaje sintaksičko jezičko sredstvo kojim se oslikava ženina pasivnost te ističe priroda njezine ljubavi prema mužu (romantične ljubavi) koja je u vječnoj konotaciji sa stidom i snebivanjem, tj. "sputana ljubav" koja ne umije ili ne nalazi način da se iskaže, a čiji rezultat je izražen modalnim glagolom dare (usuditi se), she dares not come, što, u određenom smislu, ima konotaciju s bojazni. Kao što možemo vidjeti iz sljedećeg tabelarnog prikaza, i u ostalim prijevodima (E. A. Bowring, Chawner, Dyrsen i Gibson) u kojima je upotrijebljen leksem bashful ("stidljiv / koji se snebiva”) imamo konotaciju sa sputanošću.

\subsubsection{Prijevod centralnog stiha u motivu stida kod E. A. Bowringa, Chawnera, Dyrsena i Gibsona s povratnim prijevodom na bosanski jezik.}

\begin{tabular}{lll}
\hline $\begin{array}{l}\text { E. A. } \\
\text { Bowring }\end{array}$ & $\begin{array}{l}\text { Bashfully his wife delays to } \\
\text { come there. }\end{array}$ & $\begin{array}{l}\text { Stidljivo / Snebivljivo njegova } \\
\text { žena odlaže da dođe tamo. }\end{array}$ \\
\hline Chawner & $\begin{array}{l}\text { Bashfully his wife delays her } \\
\text { coming. }\end{array}$ & $\begin{array}{l}\text { Stidljivo njegova žena odlaže } \\
\text { svoj dolazak. }\end{array}$ \\
\hline Dyrsen & $\begin{array}{l}\text { But his wife's too bashful to } \\
\text { rejoin him }\end{array}$ & $\begin{array}{l}\text { No, njegova žena je isuviše } \\
\text { stidljiva da bi se ponovo } \\
\text { sastala s njim. }\end{array}$ \\
\hline Gibson & $\begin{array}{l}\text { But his bashful wife dalays, } \\
\text { and comes not. }\end{array}$ & $\begin{array}{l}\text { Ali njegova stidljiva žena } \\
\text { odgađa i ne dolazi. }\end{array}$ \\
\hline
\end{tabular}

Ova sputanost na koju upućuje izbor leksike u navedenim prijevodima okovala je i E. A. Bowringovu i Chawnerovu i Gibsonovu Hasanaginicu kao kakva moćna, a nevidljiva sila zbog koje ona u ovim prijevodima "odugovlači i odlaže" (delays) svoj odlazak mužu. Moderna psihologija prepoznaje strah kao osnovu sputanosti ljudskog bića, prije svega strah od ponižavajućeg iskustva. Stoga ovdje prepoznajemo sasvim logičan niz konotacija: snebivanje ukazuje na sputanost koja je na unutarnjem / psihološkom planu proizvod straha, a koja se na vanjskom planu manifestira spriječenim / odloženim djelovanjem, odnosno potpunim izostankom djelovanja. 
I Grayeva "bojažljiva” (timid) Hasanaginica “odlaže svoj dolazak” (delays her coming) mužu, jer kako da "ide nepozvana svome gospodaru" (shall she go unbidden to her master): "But his timid wife dalays her coming: / Shall she go unbidden to her master?” Kod Graya je u leksičko-semantičkom smislu u ovim stihovima zadržana tek naznaka izvornog motiva stida kojeg ovdje nadilazi motiv ženinog straha. Veoma slične konotacije imaju ovi stihovi i kod Hemans: "But she who loves him best, his timid bride, / Waits his commands, and weeps and sighs at home", jer i tu žena, koja ga najviše voli (she who loves him best), njegova "stidljiva / bojažljiva" nevjesta (his timid bride) sjedi kući i suze roni čekajući da aga zapovjedi njezin dolazak (waits his commands).

I Greenshields koristi glagol delay, međutim, s posve drugačijim efektom u rečeničnoj konstrukciji but modesty delay'd his Consort's footsteps ("No, skromnost zadrža njegove Druge korake") gdje je "skromnost / umjerenost / odmjerenost”, kao vrlina koju žena posjeduje, zadržala njezin odlazak mužu. Kod Greenshieldsa nije žena ta koja je "odložila" svoj odlazak, nego je to njezina dosljednost u skromnom ili odmjerenom držanju kao rezultat njezina uravnoteženog odnosa prema sebi i stvarnosti koja je okružuje, odnosno prema društvenom kontekstu u kojem se nalazi. Greenshieldsov prijevod odlikuje i vrlo formalan "visoki" stil prikladan naslovu kojim je preimenovao izvorni naslov "Hasanaginica" $\mathrm{u}$ "A Morlachian Funeral Song on the Death of the Illiustrious Wife of Asan Aga" ("Morlačka pogrebna pjesma o smrti glasovite Hasan-agine žene"). I Butler kaže da Hasan-agu žena nije mogla obići zbog "skromnosti": "But his wife could not, because of modesty" (povratni prijevod: "Ali njegova žena nije mogla zbog skromnosti”), dok se Jones u ovom kontekstu koristi leksemom "demure" s vrlo sličnim značenjem i konotacijama koje ima i pridjev modest: "But his dear wife is too demure to go" (povratni prijevod: "Ali njegova draga žena je isuviše povučena da bi išla/pošla.").

Posve druge konotacije nalazimo u leksičkom sloju prijevoda Mary Anne Burt: "Yet, Hassan's Wife bestows no fostering care" (povratni prijevod: "A ipak, Hasanova žena ne poklanja poticajnu brigu"). Ovaj prijevod čitatelju nudi jedan novi kontekst kakav ne nalazimo u izvorniku, 
a gdje Hasanaginica ne gaji nikakav osjećaj brige za mužem, niti mu poklanja brigu / pažnju / njegu (bestows no fostering care), što, za razliku od nje, čine majka i sestra koje su tu da se "pobrinu o njemu, da mu pruže njegu i budu na usluzi" (tend him there) nakon što je "onesposobljen ranom" (disabled by a wound), "zadobijenom usljed junački izvojevane pobjede" (received amid a victory, bravely won). U prijevodu motiva stida kod autorice Burt čitatelj se, dakle, umjesto s konotacijama koje potiču zapitanost i začudnost, susreće s eksplicitno negativnim konotacijama.

\section{Zaključak}

U analizi leksičkog sloja zagonetnog motiva stida kod svih prevoditelja na engleski, a na osnovu konotacija koje polučuje prijevod ovog motiva, mogli bismo izdvojiti prijevode J. Bowringa, Kroeker, Butlera, Pennington i Levija, Jonesa te Sadiković kao najbliže izvorniku u smislu minimalnih razlika u stepenu interpretacijske ograničenosti / nametljivosti. Svi ovi prijevodi, s određenom leksičkom varijacijom, govore o teško ranjenom Hasan-agi (severely wounded, sore sick of wounds high fatal, suffering from terrible wounds, fevered with angry wounds, badly wounded, injured in pain) a da eksplicitno ne spominju bojište ili rat. Butlerov prijevod ovog stiha je gotovo identičan izvorniku, dijeli ga samo jedna riječ od doslovnog prijevoda, pridjev terrible umjesto bitter. Zanimljivo je da nijedan prevoditelj nije koristio sintagmu bitter wounds, koja nije neobična za engleski jezik. Smatramo da bi pridjev bitter ("gorak, ogorčen, žestok, ljut") bolje oslikavao izvorni termin nego što to čini terrible ("strašan, užasan, grozan, strahovit"), a razlika je u mogućnosti simboličke konotacije rana i s emocijama gorčine, ljutine i žestine bola na što upotrijebljeni pridjev terrible ne upućuje na isti način. Ovdje se i pridjev severe (ozbiljan, strog, žestok, ljut, opak), koji J. Bowring koristi kao prilog severely, može smatrati konotacijski adekvatnim leksemom.

Radnja u stihu "Oblazi ga mater i sestrica” je u ovim prijevodima izražena glagolima: seek ("tražiti, nalaziti”), visit ("posjetiti, obići”), go to ("odlaziti”), sit by ("sjediti / biti uz") i give care ("njegovati”). Najadekvatniji 
od ponuđenih glagola iz leksikostilističke perspektive bi u ovom slučaju bio visit.

U ovom se stihu susrećemo i s hipokoristikom ili odmilicom izraženom deminutivom imenice sestra, tj. sestrica, u čijem prevođenju, odnosno prenošenju se okušavaju jedino Pennington i Levi. Odmilicama ili riječima koje se koriste odmila iskazuje se intiman, prisan odnos, a služe ekspresivnom pojačavanju izraza. Pennington i Levi prenose u engleski ovaj deminutiv imeničkom sintagmom young sister ("mlada / mala sestra / seka"), dok ga Mihailovich izražava sintagmom dear sister ("draga sestra").

Već komentiran, ključni stih motiva stida je najzornije dočaran leksičkim izborom Jonesova stiha "But his dear wife is too demure to go". Međutim, na konačni izbor leksike će utjecati i drugi aspekti izvornog teksta, poput njegova strogo određenog metričko-ritmičkog obrasca, koji od posvećenog prevoditelja poezije naprosto zahtijeva očuvanje i formalnih karakteristika ove balade u onoj mjeri u kojoj je to moguće, što ne možemo kazati da Jonesov prijevod, iako u leksičkostilističkom smislu ponajbliži izvornoj baladi, čini. Rezultate jedne dublje leksikostilističke analize izvornika valja odvagati u odnosu na rezultate analize i ostalih jezičko-stilističkih nivoa izraza (fonostilističkog i sintaksostilističkog), kako bi se mogla napraviti njihova što bolja sinteza koja bi rezultirala jednim efektnijim i vjerodostojnijim prijevodom ovog usmenoknjiževnog remek-djela.

\section{Izvori i literatura}

Arnautović, Amina (2017): Lingvostilistička analiza engleskih prijevoda "Hasanaginice", doktorska disertacija, Univerzitet "Džemal Bijedić" u Mostaru, Fakultet humanističkih nauka, Mostar.

Aytoun, William Edmondstoun (1844): "The Doleful Lay of the Noble Wife of Asan Aga", Blackwood's Edinburgh Magazine 56, 67-68.

Bancroft, George (1855): "Mournful History of the Noble Wife of Asan Aga", u: Literary and Historical Miscellanies, Harper, New York, 231-235, 480-484, 
Barić, Henrik (1938): “Tragika u pesmi 'Hasanaginica”, Prilozi proučavanja narodne poezije V/2, Beograd, 169.

Bowring, Edgar Alfred (1853): "Death-Lament of the Noble Wife of AsanAga", u: Parker, John W., Poems of Goethe - Translated in Original Metres, London, 197-199.

Bowring, John (1827): “Hassan Aga's Wife's Lament”, u: Servian Popular Poetry, Baldwin, Cradock, \& Joy, London, 52-57.

Burt, Mary Anne (1853): "Lament of Hassan Aga's Noble Wife - Imitated from the Moorish", u: Specimens of the Choiciest Lyrical Productions of the Most Celebrated German Poets from Klopstock to the Present Time, Zurich.

Butler, Thomas (1980): "Hasan Aga's Wife", u: Monumenta Serbocroatica, Michigan Slavic Publications, Ann Arbor, 417-422.

Chawner, Edward (1866): "Elegy on the Noble Wife of Assan Aga", u: Goethe's Minor Poems, Pitman, London, 99-102.

Dizdar, Nerin (2011): Semantički i sociolingvistički aspekti engleskih prijevoda balade "Hasanaginica", magistarski rad, Fakultet humanističkih nauka, Univerzitet "Džemal Bijedić" u Mostaru, Mostar.

Dyrsen, Paul (1878): "Lamentation of Asan Aga's Noble Wife - From the Morlackish", u: Christern, F. W., Goethe's Poems, translated in the original metres, New York, 211-214.

Gesemann, Gerhard (1923): "Die Asanaginica im Kreise ihrer Varianten”, Archiv für slavische Philologie XXXVIII, 1-44.

Gibson, William (1883): “The Lament of the Noble Wife of asan Aga”, u: The Poems of Goethe, Simpkin, London, 31-34.

Gray, M. (1890): “A Serbian Story - Asan-Aginitza”, u: Douglas, D., Lyrics and Epigrams - After Goethe and Other German Authors, Edinburg, 23-26.

Greenshields, John Boyd (1800): "A Morlachian Funeral Song of the Death of the Illustrious Wife of Asan Aga - From the German of Goethe", u: Selim \& Zaida - an Oriental Poem with Other Pieces, London, 149-154.

Gregorijević, Krešimir (1952): "Murkova Hasanaginica”, u: Književne studije $i$ ogledi, Matica srpska, Novi Sad. 
Hemans, Felicia Dorothea (1836): “The Divorce; or, the Wife of Hassan Aga From the German of Göethe, the Author of Werter", u: Lawrence, Rose (ur.) The Last Autumn at a Favourite Residence, with other poems, and recollections of Mrs. Hemans, Evans, Chegwin and Hall, Liverpool.

Hodžić, Jasmin (2014): "O nekim jezičkim i društvenim aspektima narodne balade o žalosnoj i plemenitoj Hasanaginici”, u: Ogledi iz lingvistike $i$ filologije, Narodna biblioteka Mostar, Mostar, 177-195.

Isaković, Alija (1975): Hasanaginica, 1774-1974, Svjetlost, Sarajevo.

Jones, Francis (2017): “The Sad Ballad of the Noble Lady Hasan Aginica”, dostupno na: http://citeweb.info/20102389159.

Krnjević, Hatidža (1973): Usmene balade Bosne i Hercegovine: knjiga o baladama i knjiga balada, Svjetlost, Sarajevo.

Kroeker, Kate Freiligrath (1879): "The Wife of Hassan Aga", Dublin University Magazine 95, 292-294.

Lucerna, Camilla (1905): Die Südslavische Ballade von Asan Agas Gattin und ihre Nachbildung durch Goethe, Verlag von Alexander Duncker, Berlin.

Mahmutćehajić, Rusmir (2010): Tajna Hasanaginice, Buybook, Sarajevo.

Mangan, James Clarence (1836): "Hassan Aga”, Dublin University Magazine 7, 295-298.

Meredith, Owen (Lytton, Edward Robert Bulwer) (1861): "The Wife of Hassan Aga", u: Serbski Pesme: or National Songs of Servia, ChapmanHall, London, 120-127.

Mihailovich, Vasa D. (1986-87): “Twenty two Translations of 'Hasanaginica' into English", Serbian Studies 4/1-2, North American Society for Serbian Studies, 65-76.

Muratagić-Tuna, Hasnija (2010): "Sevdalinka izazov za lingvostilistička istraživanja”, Bošnjačka riječ - časopis za društveni život i kulturu sandžačkih Bošnjaka V/17-18, januar - jun, 15-25.

Mügge, Maximilian August (1916): "Hasanaginica”, u: Serbian Folk Songs, Fairy Tales and Proverbs, Drane, London, 64-68.

Noyes, George Rapall; Bacon, Leonard (1913): “The Wife of Hasan Aga”, u: Heroic Ballads of Servia, Sherman-French, Boston, 271-275. 
Pennington, Anne; Levi, Peter (1983): “The Wife of Asan-aga”, u: Marko the Prince: Serbo-Croat Heroic Songs, Duckworth, London, 168-170.

Rizvić, Muhsin (1994): Panorama bošnjačke književnosti, NIPP Ljiljan, Sarajevo.

Sadiković, Amira (2017): "Hasanaginica”, u: Sevdah, Vrijeme, Zenica, 25-27.

Scott, Walter (1924): "The Lamentation of the Faithful Wife of Asan Aga From the Morlachian Language", Edinburgh University library, 17941798 (?), The Slavonic and East European Review 3, 366-369.

Seton-Watson, Robert William (1932): "Lament of the Noble Wife of Hassan Aga", The Slavonic and East European Review 11/31, 134-137.

Venuti, Lawrence (1998): The Scandals of Translation, Routledge, London New York.

Wagner, Aleksandra (2008): “The Woman Who Knew Too Much", Cabinet Magazine 31, Shame, Fall 2008. dostupno na: http://www.cabinetmagazine.org/issues/31/wagner.php (1. 12. 2021)

Wilson, Duncan (1970): "Hasanaginica - The Wife of Hasan Aga", u: The Life and Times of Vuk St. Karadžić 1787-1864; Literacy, Literature and National Independene in Serbia, Clarendon Press, Oxford, 361-363.

Zimmerman, Zora Devrnja (1986): "Hasanaginica”, u: Serbian Folk Poetry: Ancient Legends. Romantic songs, Columbus OH, Kosovo, 239-243. 


\title{
Connotations of the lexical layer of shame motif in English translations of Bosniak ballad "Hasanaginica"
}

\begin{abstract}
Translating a work of literary art, especially poetry, also means translating its style. At the lexico-stylistic level, style manifests itself in both denotative and connotative meanings of the lexical units of a text. By analyzing the connotations of the lexical layer of shame motif in English translations of Bosniak ballad "Hasanaginica", we can identify and problematize the interpretation of this motif in the target texts in relation to the source text. Applying the method of lexico-stylistic analysis to the key verses of the shame motif, both in the source text and in the target texts in English, we examine the ways in which different translators build the mystical motif as the only abstract concept that never develops into a poetic image, leaving space for multi-layered connotations that are imposed on the reader. The results of the analysis point to the translations that are closest to the source text in terms of containing minimal differences in the degree of their interpretive limitation or intrusiveness. The most vividly evoked key verse of the shame motif is found in Francis Jones' translation. However, the final vocabulary choice made by a discerning translator possessing a high degree of stylistic awareness should also be influenced by other aspects of the original text, such as its established rhythmic pattern or meter that requires preservation and other formal characteristics of this ballad, which are not to be found in Jones' translation. Therefore, our conclusion is that the results of lexico-stylistic analysis of the original should be weighed against the results of analysis on other linguo-stylistic levels of expression (phonostylistic and syntaxostylistic) in order to synthesize them as successfully as possible, which could help recreate a new, more effective and reliable translation of this masterpiece of our oral literature.
\end{abstract}

Key words: lexico-stylistic analysis, motif of shame, connotations, English translations of Bosniak ballad "Hasanaginica"

\section{Izjava autora o nepostojanju sukoba interesa i poštivanju općih etičkih kodeksa:}

Autor potvrđuje da ne postoji nikakav stvarni ili mogući sukob interesa vezan za ovaj tekst te da je tekst napisan u skladu s etičkim kodeksima prema preporukama COPE (Committee of Publishing Ethics). 